\title{
Role of Environmental Factors in Enhancing Financial Capability of Beneficiaries under Pradhanmantri Jan Dhanyojana (PMJDY) of Assam Graminvikash Bank of Nalbari District of Assam
}

\author{
Tandraleem Kashyap, Ratan Borman
}

\begin{abstract}
Financial capability is the skill, knowledge, and dispositions that enable a person to make well-informed financial decisions throughout their lives. The concept of financial capability connotes both ability and opportunity. The key elements that determine financial capability are-i) knowledge, ii) skills, iii) confidence and attitudes and iv) responsible financial decision. The financial capability factors are best understood as a combination of characteristics that may act as barriers or enablers to financially capable behaviour. They split into-i) internal capability, which is influenced by-personal factors and ii) external capability which is influenced by societal factors and environmental factors. The main objective of this study is to examine the various environmental factors that influence financial capability building efforts of beneficiaries under Pradhan Mantri Jan Dhan Yojana (PMJDY). The paper is of descriptive and analytical in nature and based on primary and secondary data.
\end{abstract}

Key Words: Financial Capability, Environmental Factors, Financial decision.

\section{INTRODUCTION}

Financial capability is about having the financial knowledge, understanding, confidence and motivation to make good financial decisions. Financial capability, defined by the World Bank as, "it is the capacity to act in one's best financial interest, given socio-economic and environmental conditions. It encompasses knowledge (literacy), attitudes, skills and behavior of consumers with respect to understanding, selecting, and using financial services, and the ability to access financial services that fit their needs". The financial behaviors of an individual are influenced by various factors. The financial capability factors are best understood as a combination of characteristics that may act as barriers or enablers to financially capable behavior and these are- personal factors, social factors and environmental factors. Among the three factors one of the most important factor which influence an individual's financial capability is environmental factors.Environmental factors are external to the individual and can have a positive or negative influence on a person's participation as a member of society, on performance of activities, or on a person's body function or structure. Many factors can be included in the category of environment factors and thesefactors can prevent an individual from demonstratinghis/her true level of financial capability. Such

Revised Manuscript Received on November 15, 2019

Tandraleem Kashyap, Research Scholar, Deptt. of Commerce, Assam University, Diphu Campus, Karbi Anaglong, Assam

Prof. Ratan Borman, HOD, Deptt. of Commerce, Assam University, Diphu Campus, Karbi Anaglong, Assam

factors includebarriers to access finance, financial servicesprovision, behavior of financial firms and consumer protection legislation etc.

\section{STATEMENT OF THE PROBLEM}

There are good numbers of financial institutions are operating in our country and engaged in providing various kinds of financial services to the different sections of the society, but financial capability enhancement is not known in making financial wealth of the people and unable to build their financial capability. PradhanMantri Jan DhanYojana (PMJDY) is an enormous step taken by the Government of India on $28^{\text {th }}$ August, 2014 which aims to give universal access to banking facilities for all households across the country.Under the PMJDY scheme, as on $31^{\text {st }}$ March, 2018, total $31,44,39,129$ accounts have been opened in India and Rs. 7849399.24 (in lac) have been found to be deposited. ${ }^{2}$ However though a significant number of accounts have been opened; often it is alleged that sizeable number of the accounts are dormant or with low volume of transactions. It is found that, most of the accounts opened at public sector banks under the PMJDY, only $28 \%$ are active. ${ }^{3}$ Such state of affairs depicts a dismal picture on the move and spirit of PMJDY and achieving economic autonomy of the weaker and low income group population through the effort of enhancement of financial capability. Thus, there is an urgent need to examine the fact which is responsible for such state of affairs. Therefore to investigate into matter, the study is designed to focus on the financial capability building efforts through PMJDY in the Nalbari district of Assam.

\section{REVIEW OF LITERATURE:}

Atkinson et al. (2006, 2007), on a survey commissioned to explicitly measure financial capability in Britain (FSA 2006b), identify five contributory domains: making ends meet, managing money, planning ahead, choosing products and staying informed. They create scores

${ }^{2}$ World Bank Group, Zambia (2007), "Enhancing Financial Capability and Inclusion in Zambia", www.worldbank.org,accessed on $15^{\text {th }}$ December, 2017

${ }^{2}$ https://www.pmjdy.gov.in/BankwiseLatest, accessed on $4^{\text {th }}$ August, 2018 ${ }^{3}$ Gupta, S. K. (2015), "Performance Appraisal of the Pradhan Mantra Jan DhanYojna" IOSR Journal of Business and Management (IOSR-JBM) eISSN: 2278-487X, p-ISSN: 2319-7668, Volume 17, Issue 9, pp. 35-39 www.iosrjournals.org, accessed on $7^{\text {th }}$ August, 2018. and $E_{n_{2}}$ 


\section{Role of Environmental Factors in Enhancing Financial Capability of Beneficiaries under Pradhanmantri Jan Dhanyojana (PMJDY) of Assam Graminvikash Bank of Nalbari District of Assam}

within each domain and conclude that older people, people with higher incomes and those in couples with no dependent children have greatest financial capability while younger people, people in couples with dependent children, single people and those with lower income have least. ${ }^{4}$

According to McCormick (2009), the term financial capability is intended to include not only the concept of education but also access to financial services and institutions, arguing that knowledge alonewithout access to the resources and services of financial institutions, especially for those coming from under or unbanked communities will not ultimately allow people to choose a financially literate lifestyle. ${ }^{5}$

According to Dasgupta and Anklesaria (2015), the key challenges which could hinder the success of PMJDY which are infrastructural issues pertaining within India, ability to keep the accounts 'live', lack of financial and technological literacy amongst the masses, duplication of accounts, managing the ecosystem of business correspondents and the economic burden on stakeholders of keeping these accounts active. They have identified that with the development of PMJDY scheme stakeholders like RBI, central and state government, banks, local bodies, government agencies like NABARD, NPCI etc. will have to build a sustainable ecosystem to keep these accounts active. ${ }^{6}$

Gupta, S. K. (2015) highlighted on Performance of the PradhanMantri Jan DhanYojana (PMJDY) and latest trends being implemented for financial inclusion by PMJDY. It is found that, of the accounts opened at public sector banks under the Jan DhanYojana, $71 \%$ are zero balance, against $64 \%$ for private banks released by the ministry, only $28 \%$ of the accounts opened under the scheme are active, with about Rs.9,000 crores deposited in these. $^{7}$

\section{RESEARCH GAP}

The matter of financial capability is most talked about and highly pertinent in the today's world. From the reviewed literature, it is evident that various studies have been conducted on financial literacy, financial education, financial capability and its relation with the individual's financial well-being. However, no specific study on environmental factors of financial capability have been accomplished particularly in geographical and segmental dimension in the district of Nalbariwith reference to weaker and low income group, who are direct beneficiaries under PMJDY and more so in the context of Assam on the matter under consideration, resulting a research gap.

\footnotetext{
${ }^{4}$ Atkinson, A., McKay, S., Kempson, E. \& Collard, S., (2006), "Levels of financial capability in the UK: Results from a baseline survey", FSA Consumer Research Paper 47. London: FSA.

${ }^{5}$ McCormick, M. H. (2009), "The Effectiveness of Youth Financial Education: A Review of Literature", Journal of Financial Counseling and Planning, Volume 20 (1), 70-83.

${ }^{6}$ Dasgupta, A. \& Anklesaria, E. (2015), "Pradhan Mantri Jan Dhan Yojana", KPMG report.

7 Gupta, S. K. (2015), "Performance Appraisal of the Pradhan Mantra Jan Dhan Yojna" IOSR Journal of Business and Management (IOSR-JBM) eISSN: 2278-487X, p-ISSN: 2319-7668, Volume 17, Issue 9, pp. 35-39 www.iosrjournals.org, accessed on $7^{\text {th }}$ August, 2018.
}

\section{RESEARCH OBJECTIVES}

The primary objective of this paper is to analyse the role of environmental factors that influence financial capability enhancement of beneficiaries under PradhanMantri Jan DhanYojana (PMJDY) of Assam GraminVikash Bank of Nalbari, Assam.

\section{RESEARCH METHODOLOGY}

The study is descriptive and analytical in nature. For the purpose of the study 50 samples is drawn out by using convenient sampling. The study is based on both primary and secondary data. Primary data is collected through structured schedule from different PMJDY beneficiaries of Assam GraminVikash Bank of Nalbari, Assam for the purpose and interaction/observation. The relevant secondary data is collected from the data bases of Reserve Bank of India (RBI) and the concern Report of Banks, relevant books, articles from journals and newspapers. Collected data are brought under applicable and very simple and meaningful statistical treatment in order to synthesize and to categorically conclude for the better justifications. The data so collected are tabulated, analysed andpresented using percentage and charts.

\section{DISCUSSION \& ANALYSIS}

The data collected are tabulated and analyzed as under-

Table: 1: Demographic and Socio-economic status of respondents

\begin{tabular}{|c|c|c|c|}
\hline Variable & Category & Frequency & $\%$ \\
\hline \multirow{3}{*}{$\begin{array}{l}\text { Area of } \\
\text { Residence }\end{array}$} & Rural & 33 & 66 \\
\hline & Semi-urban & 17 & 34 \\
\hline & Urban & 0 & 0 \\
\hline \multirow[t]{2}{*}{ Sex } & Male & 29 & 58 \\
\hline & Female & 21 & 42 \\
\hline \multirow[t]{4}{*}{ Age(Years) } & $20-30$ & 8 & 16 \\
\hline & $30-40$ & 16 & 32 \\
\hline & $40-50$ & 17 & 34 \\
\hline & Above 50 & 9 & 18 \\
\hline \multirow[t]{2}{*}{ Marital Status } & Married & 31 & 62 \\
\hline & Unmarried & 19 & 38 \\
\hline \multirow[t]{4}{*}{ Qualification } & HSLC & 19 & 38 \\
\hline & $\mathrm{HS}$ & 13 & 26 \\
\hline & Graduate & 10 & 20 \\
\hline & Others & 8 & 16 \\
\hline \multirow[t]{5}{*}{ Occupation } & Daily wager & 19 & 38 \\
\hline & Marginal farmer & 15 & 30 \\
\hline & Business & 11 & 22 \\
\hline & Households & 5 & 10 \\
\hline & Others & 0 & 0 \\
\hline \multirow{3}{*}{$\begin{array}{l}\text { Income per } \\
\text { annum }\end{array}$} & Below Rs. 10000 & 8 & 16 \\
\hline & Rs. $10000-20000$ & 30 & 60 \\
\hline & Rs. $20000-27000$ & 12 & 24 \\
\hline
\end{tabular}




\section{Source: Compiled from primary data}

The demographic characteristic of the respondents reveals in Table: 1 , that majority of the respondents are i.e. $66 \%$ of the respondent belongs to rural area and $34 \%$ belongs to semi-rural area and there was no respondent from urban area.58\% of respondents were male and $42 \%$ respondents were female, $16 \%$ belong to the age category of 20-30 years, $32 \%$ of the respondents belong to the age category of $30-40$ years, $34 \%$ belong to the age category of $40-50$ years, $18 \%$ belong to the age category of above 50 years. It has also observed that $62 \%$ of the sample household persons were married and $38 \%$ were unmarried. Out of 50, respondents surveyed 38\% have completed their High School Leaving exam, $26 \%$ have completed their Higher Secondary Level exam, 20\% have completed their Graduation and $16 \%$ responded that they have left their studies in their early age. It has been found that $38 \%$ of the respondents were daily wage earner, $30 \%$ were marginal farmers, $22 \%$ were engaged in some business, $10 \%$ were households and there was no respondent with other occupation. It has been also identified that, $16 \%$ respondent's yearly earning is below Rs. $10000,60 \%$ of the sample respondent's yearly earning ranges between Rs. $1000-20000,24 \%$ of the sample respondent's yearly earning ranges between Rs. 20000-27000.

Table: 2: Nature of financial product/service purchased by sample respondents

\begin{tabular}{|c|l|c|c|c|}
\hline $\begin{array}{c}\text { Sl. } \\
\text { No }\end{array}$ & $\begin{array}{l}\text { Product/Servic } \\
\mathrm{e}\end{array}$ & $\begin{array}{c}\text { No. of } \\
\text { Respond }^{\mathrm{t}}\end{array}$ & $\begin{array}{c}\text { Total } \\
\text { Respond }^{\mathrm{t}}\end{array}$ & $\begin{array}{c}\text { Proportionate } \\
\%\end{array}$ \\
\hline 1 & $\begin{array}{l}\text { Saving } \\
\text { Accounts }\end{array}$ & 50 & 50 & 100 \\
\hline 2 & $\begin{array}{l}\text { Bank Fixed } \\
\text { Deposits }\end{array}$ & 12 & 50 & 24 \\
\hline 3 & $\begin{array}{l}\text { National } \\
\text { Saving } \\
\text { Certificates }\end{array}$ & 9 & 50 & 18 \\
\hline 4 & $\begin{array}{l}\text { Post Office } \\
\text { Savings }\end{array}$ & 11 & 50 & 22 \\
\hline 5 & Loan/mortgage & 19 & 50 & 38 \\
\hline 6 & Life Insurance & 8 & 50 & 16 \\
\hline 7 & Others & 0 & 50 & 0 \\
\hline
\end{tabular}

From the proportionate percentage of Table:2, it is seen that all the respondents have savings bank accountand very less respondents have purchased bank fixed deposit, National Saving Certificates, Post Office Savings, Loan/mortgage, Life Insurance etc. The sample respondents have not purchased any other financial products/services yet. Accordingly the respondents were asked to give their opinion in the rank wise of the likely factors/challenges which may act as a barrier while accessing finance from any financial institutions. The summary of the table depicts the rank of the factors/challenges on the basis of the opinion of the respondents.

Table: 3: Factors/challenges which may act as barrier while accessing finance

\begin{tabular}{|c|l|c|c|c|}
\hline $\begin{array}{c}\text { Sl. } \\
\text { No }\end{array}$ & \multicolumn{1}{|c|}{ Factors } & $\begin{array}{c}\text { No. of } \\
\text { Respnd }^{\mathrm{t}}\end{array}$ & $\begin{array}{l}\text { Proportio } \\
\text { nate \% }\end{array}$ & Rank \\
\hline 1 & $\begin{array}{l}\text { Far distance to bank } \\
\text { institutions }\end{array}$ & 14 & 28 & 5 \\
\hline 2 & $\begin{array}{l}\text { Time consuming banking } \\
\text { procedure }\end{array}$ & 29 & 58 & 2 \\
\hline
\end{tabular}

\begin{tabular}{|c|l|c|c|c|}
\hline 3 & $\begin{array}{l}\text { Lack of proper } \\
\text { documentation }\end{array}$ & 37 & 74 & 1 \\
\hline 4 & $\begin{array}{l}\text { Inadequate financial } \\
\text { product/services }\end{array}$ & 8 & 16 & 6 \\
\hline 5 & $\begin{array}{l}\text { Non-availability of ATM } \\
\text { services }\end{array}$ & 3 & 6 & 7 \\
\hline 6 & $\begin{array}{l}\text { Unavailability of bank } \\
\text { mitras }\end{array}$ & 16 & 32 & 4 \\
\hline 7 & $\begin{array}{l}\text { Bank's poor attention } \\
\text { towards customer }\end{array}$ & 22 & 44 & 3 \\
\hline 8 & \begin{tabular}{l} 
None of the above \\
\hline
\end{tabular}
\end{tabular}

Source: Compiled from primary data

The respondents were asked to give their opinion relating to the bank employees behavior or services provided towards its customers like, filling up of deposit forms/withdrawal forms, enlighten about bank procedures, aware about various financial products/services and giving quick services and responses are analyzed using the below diagram-

\section{Chart: 1: Bank employee's behavior}

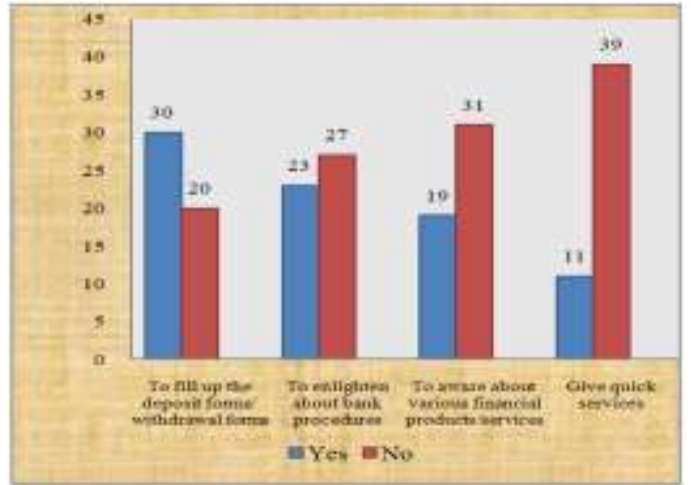

Source: Compiled from primary data

Out of the 50 respondents, $4 \%$ opinioned that the attitude of bank employees are highly supportive, $16 \%$ opinioned the attitude of bank employees are supportive,

$34 \%$ opinioned the attitude of bank employees are moderately supportive and $46 \%$ opinioned the attitude of bank employees are non-supportive. The collected data are presented with a pie chart below-

Chart: 2: Responses relating toattitudes of employees of banking institutions

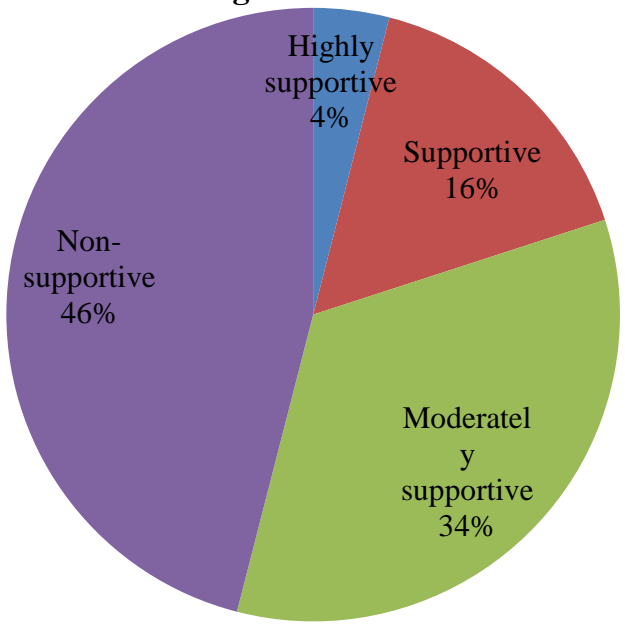

Published By:

Blue Eyes Intelligence Engineering 


\section{Role of Environmental Factors in Enhancing Financial Capability of Beneficiaries under Pradhanmantri Jan Dhanyojana (PMJDY) of Assam Graminvikash Bank of Nalbari District of Assam}

\section{Source: Compiled from primary data}

When the samples were asked about the grievance redressal mechanism of banking institutions under Banking Ombudsman and Consumer Forum, it was found that no respondents were aware about these mechanisms. Among the 50 respondents $35 \%$ have faced various problems and lodged complaints regarding any financial products/services they are dealing with and their complaint has been settled within 1-2 months. The nature of complaint lodged were regarding incorrect bank balance, loan disbursement, updates relating to matured Fixed Deposits and various ATM issues.

According to the $16 \%$ of the sample respondents, their financial condition was better before opening PMJDY account. Accordingly $72 \%$ responded that their financial condition become better after opening PMJDY account and $12 \%$ responded that there is no change in their financial condition. The data are presented using a chart below-

Chart: 3: Opinion regarding financial condition

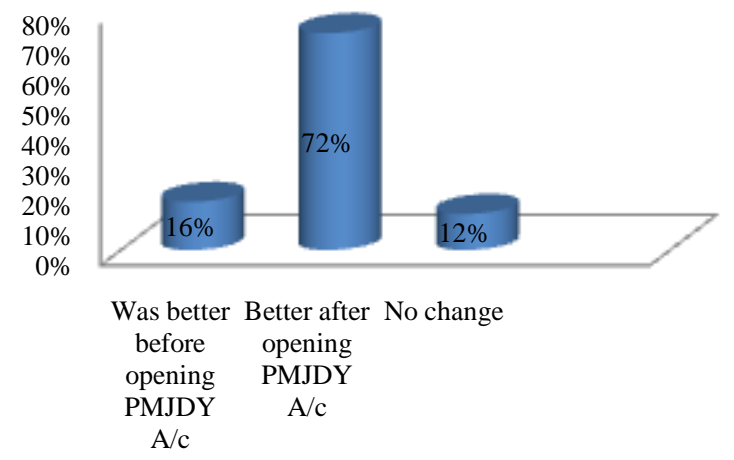

\section{Source: Compiled from primary data}

Finally the respondents were examined whether their financial capability enhanced or not after coming under the PMJDY scheme and for that purpose some financial capability determinants were identified and data were collected accordingly. It was inferred that the various financial capability determinants of sample respondents like, living within one's means, monitoring expenses, planning for unexpected expenses, saving capacity, planning for old age expenses, responsible behavior, choosing financial products/services and attitude towards the future have increased as the weighted mean 2.34, 2.38, 2.54, 2.12, 2.74, $2.02,2.22$ and 2.7 accordingly is found above par value i.e. 2. But the sample respondents were found to be lagging behind in controlled budgeting and using of financial information as the weighted mean was 1.94 and 1.92 . It can be observed that the overall financial capability of the respondents have enhanced through the PMJDY scheme.

Table: 4: Extent of enhancement of various financial capability determinants

\begin{tabular}{|c|l|c|c|c|c|c|}
\hline $\begin{array}{r}\text { Sl. } \\
\text { No. }\end{array}$ & \multicolumn{1}{|c|}{ Variable } & $\begin{array}{c}\text { Fully } \\
(3)\end{array}$ & $\begin{array}{c}\text { Partially } \\
(2)\end{array}$ & $\begin{array}{c}\text { Not at } \\
\text { all (1) }\end{array}$ & $\begin{array}{c}\text { No. of } \\
\text { Respond }^{\mathrm{t}}\end{array}$ & $\begin{array}{l}\text { Wg.hte } \\
\text { d Mean }\end{array}$ \\
\hline 1 & Controlled Budgeting & 11 & 25 & 14 & 50 & 1.94 \\
\hline 2 & $\begin{array}{l}\text { Living within one's } \\
\text { means }\end{array}$ & 20 & 27 & 3 & 50 & 2.34 \\
\hline 3 & Monitoring expenses & 19 & 31 & 0 & 50 & 2.38 \\
\hline 4 & $\begin{array}{l}\text { Planning for } \\
\text { unexpected expenses }\end{array}$ & 27 & 23 & 0 & 50 & 2.54 \\
\hline 5 & Saving Capacity & 13 & 30 & 7 & 50 & 2.12 \\
\hline 6 & $\begin{array}{l}\text { Planning for old age } \\
\text { expenses }\end{array}$ & 37 & 13 & 0 & 50 & 2.74 \\
\hline
\end{tabular}

\begin{tabular}{|c|l|c|c|c|c|c|}
\hline 7 & $\begin{array}{l}\text { Using Financial } \\
\text { information }\end{array}$ & 9 & 28 & 13 & 50 & 1.92 \\
\hline 8 & Responsible Behavior & 9 & 33 & 8 & 50 & 2.02 \\
\hline 9 & $\begin{array}{l}\text { Choosing Financial } \\
\text { products/services }\end{array}$ & 15 & 31 & 4 & 50 & 2.22 \\
\hline 10 & $\begin{array}{l}\text { Attitude towards the } \\
\text { future }\end{array}$ & 35 & 15 & 0 & 50 & 2.7 \\
\hline
\end{tabular}

\section{CONCLUSION}

This study empirically investigates a positive role of various environmental factors in enhancing financial capability of beneficiaries under Pradhan Mantri Jan Dhan Yojana (PMJDY). It is seen that it can act as barrier as well as enabler in building an individual's financial capability as environmental factors are the most vital factors among all the factors of financial capability. Financial capability not only includes financial concepts but also includes behavioral factors, emotions, social influences and individual access to financial products and services. The policymakers should improve all the environmental factors so that they can play a positive and strong role in building one's financial capability.

Moreover they should give importance in spreading the awareness about the various financial product/services to make them more financially capable. The banking procedures should be made easy and the customers need to make aware about the various grievance redressal mechanism so that they can feel secure in investing in banking institutions. With the help of PMJDY account people are getting the various benefits of Government schemes like Ujjala Yojana, Pradhan Mantri Kisan Pension Yojana, Suknya Samriddhi Yojana, Pradhan Mantri Jeevan Jyoti BimaYojana, Pradhan Mantri Surakshya Bima Yojana, Kisan Samman Nidhi, Ayushman Bharat Yojana directly in their bank account. It is a great step towards making the people of the society financially stable and strong. Though the possibility of the financial capability approach is quite vast, it considers all probable features-personal, economic, social, political, or environmental that can possibly influence human capabilities which dictate the real wellbeing of people.

\section{REFERENCES}

1. Dasgupta, A. \& Anklesaria, E. (2015), "Pradhan Mantri Jan Dhan Yojana", KPMG report.

2. Financial Capability Surveys Around the World (2013), "Why Financial Capability is important and how surveys can help", www.worldbank.org/fpd, accessed on $15^{\text {th }}$ December 2017

3. Gupta, S. K. (2015), "Performance Appraisal of the Pradhan Mantra Jan Dhan Yojna" IOSR Journal of Business and Management (IOSR JBM) e-ISSN: 2278-487X, p-ISSN: 2319-7668, Volume 17, Issue 9 , pp. 35-39 www.iosrjournals.org, accessed on $7^{\text {th }}$ August, 2018.

4. https://www.pmjdy.gov.in/BankwiseLatest, accessed on $4^{\text {th }}$ August, 2018

5. Julia M. Smith-Brake (2011), "Enhancing Financial Capability Among Youth in Hochelaga-Maisonneuve (Québec,Canada)",https://academicarchive.snhu.edu/bitstream/handle $110474 / 1852 /$ sced2011smith-brake.pdf; sequence $=1$, accessed on $18^{\text {th }}$ December, 2017

6. Kumar, V. (2017), “An assessment of Pradhan Mantri Jan-Dhan Yojana",International Journal for Innovative Research in Multidisciplinary field, ISSN - 2455-0620 Volume - 3, Issue - 7, July 
7. Kunthia, R. (2014), "Pradhan Mantri Jan Dhan Yojana (PMJDY): A new drive towards financial inclusion in India", ZENITH International Journal of Business Economics \& Management Research, Volume 4, No.11, pp.10.

8. McCormick, M. H. (2009), "The Effectiveness of Youth Financial Education: A Review of Literature", Journal of Financial Counseling and Planning, Volume 20 (1), 70-83.

9. Ministry of Education, New Zealand Government (2014), "Development of the Financial Capability Progressions", https://nzcurriculum.tki.org.nz/.../Development $\% 20$ of $\% 20$ the\%20Fin ancial\%20Capability\%20progression.docx,accessedon $18^{\text {th }}$ December, 2017

10. Patnaik, B., Satpathy, I. \& Supkar, A. C. (2015), "Pradhan Mantri Jan Dhan Yojna (Pmjdy) - A new direction for mainstreaming the financially excluded", International Journal of Management, pp. 3142 .

11. Sherraden, M. S. (2010), "Financial Capability: What is It, and How Can It Be Created?", Center for Social Development Working Papers No. 10-17, Washington University in St. Louis George Warren Brown School of Social Work.

12. Sherraden, M. S. et al (2015), "Financial Capability and Asset Building for All", American Academy of Social Work and Social Welfare, working paper No. 13

13. World Bank Group, Zambia (2007), "Enhancing Financial Capability and Inclusion in Zambia", www.worldbank.org,accessed on $15^{\text {th }}$ December, 2017

14. Yoong, J. et al. (2013), "A toolkit for the evaluation of financial capability programs in low- and middle-income countries", Financial Literacy and Education Fund- Russia Trust Fund, www.worldbank.org.accessed on $15^{\text {th }}$ December 2017

\section{AUTHOR'S PROFILE}

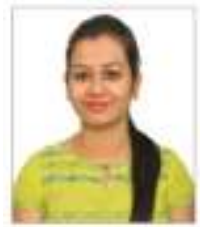

First Author:Tandraleem Kashyap, daughter of Dr. Ashok Kumar Sarma and wife of Hemanga Goswami is a resident of Bijoynagar, Guwahati, Assam. She did M.Com. (double) from Gauhat University, Asssam in the year 2014 and 2015 respectively. Along with this she did B.Ed. from Gauhati University, Assam in the year 2016. She did M. Phil. in 2018 from Assam University, Diphu Campus, Assam under the supervision of Prof. Ratan Borman and the title of the dissertation was "Financial Literacy and its Impact in Financial Portfolio Decisions: A case study in Nalbari Town of Assam". Presently, she has been working as an Assistant Professor in the Department of Commerce in Dakshin Kamrup College, Mirza, Assam and pursuing Ph.D. under Department of Commerce, Assam University, Diphu Campus, Assam. She has published 8research papers in various national and international journals and she is the co-author of 5 textbooks of B.Com. under Gauhati University and Dibrugarh University, Assam. She has presented 21 papers in various international and national conferences/seminars. Furthermore, Ms. Kashyap has participated in 3 national level workshops.

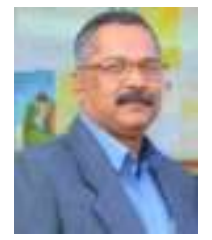

Second Author:Dr. Ratan Borman is a resident of Diphu, Assam and currently serving as Professor and Head, Department of Commerce, Assam University Diphu Campus, Assam, India. Dr. Borman has teaching experience of more than 30 years both at undergraduate and post graduate level and research experience of more than 15 years. He is a recognized research supervisor of Assam University and five scholars with $\mathrm{Ph}$. D. degree and ten scholars with M. Phil. degree have been awarded uptil now. Currently, there are eight scholars under Ph. D. programme and three scholars under M. Phil. degree have been pursuing their research under his supervision. He has 48 publications both national and international to his credit besides participation in 45 national and international seminars. He was awarded with Best Business Academic Year 2014 [Silver Medal] by Indian Commerce Association. He also holds position of Vice President of North East India Commerce and Management Association and Life Member of Indian Commerce Association. 